\title{
Fishing effort alternatives for the management of demersal fisheries in the western Mediterranean
}

\author{
Paloma Martín, Francesc Maynou, Mariona Garriga-Panisello, John Ramírez, Laura Recasens \\ Institut de Ciències del Mar, CSIC, Pg. Marítim de la Barceloneta, 37-39. 08003 Barcelona, Spain. \\ (PM) (Corresponding author) E-mail: paloma@ icm.csic.es. ORCID iD: https://orcid.org/0000-0002-5665-2695 \\ (FM) E-mail: maynouf@icm.csic.es. ORCID iD https://orcid.org/0000-0001-7200-6485 \\ (MG) E-mail: mariona.garripa@gmail.com. ORCID iD https://orcid.org/0000-0002-1869-3074 \\ (JR) E-mail: j.gabriel@icm.csic.es. ORCID iD https://orcid.org/0000-0002-0262-8200 \\ (LR) E-mail: laura@icm.csic.es. ORCID iD https://orcid.org/0000-0002-2821-1796
}

\begin{abstract}
Summary: Management alternatives based on fishing effort for the demersal fisheries in the western Mediterranean were tested, with the novelty of examining management alternatives at temporal scales smaller than one year. Nine scenarios were considered on the basis of input control: decrease in the number of fishing days, which may correspond to cessation of activity of vessels or lower activity of the fleet; and implementation of seasonal closures of one-, two- and three-month duration in winter, spring, summer and autumn. The approach is based on a multispecies and multigear bioeconomic model. We selected a total of ten species (Merluccius merluccius, Nephrops norvegicus, Mullus barbatus, Mullus surmuletus, Parapenaeus longirostris, Lophius piscatorius, Lophius budegassa, Aristeus antennatus, Phycis blennoides and Lepidorhombus boscii) and seven fleets, defined as a combination of fishing gear (bottom trawl, entangling nets and longline) and fleet segment. A similar decrease in $\mathrm{F}$ is achieved with a $20 \%$ reduction of fishing effort (days) or with two- to three-month closures. Maximum Sustainable Yield (MSY) for all stocks would be achieved only with such a drastic reduction of fishing effort ( $>80 \%$ of fishing days by the end of the five years of simulation) that, in practice, its application can be considered unrealistic, since it would represent a very low activity of all fishing fleets over the year.
\end{abstract}

Keywords: demersal fisheries; fisheries management; fishing effort; western Mediterranean.

Alternativas de esfuerzo de pesca para la gestión de las pesquerías demersales en el Mediterráneo occidental

Resumen: Se investigaron alternativas de gestión, basadas en el esfuerzo de pesca, para las pesquerías demersales del Mediterráneo occidental, con la novedad de analizar alternativas de gestión a escalas temporales inferiores a 1 año. Se consideraron nueve escenarios basados en control de entrada: disminución en el número de días de pesca, que puede corresponder a cese de actividad de las embarcaciones o a una menor actividad de la flota; y aplicación de vedas temporales de 1,2 y 3 meses de duración, en invierno, primavera, verano y otoño. Se ha trabajado con un modelo bioeconómico, multi-especies y multi-arte. Se seleccionó un total de 10 especies (Merluccius merluccius, Nephrops norvegicus, Mullus barbatus, Mullus surmuletus, Parapenaeus longirostris, Lophius piscatorius, Lophius budegassa, Aristeus antennatus, Phycis blennoides, Lepidorhombus boscii) y 7 flotas, definidas como una combinación de arte de pesca (arrastre de fondo, redes de enmalle y palangre) y segmento de flota. Se consigue un mismo descenso en F con una reducción del $20 \%$ del esfuerzo de pesca (días de pesca) o con vedas de 2-3 meses de duración. MSY para todos los stocks se alcanzaría con una reducción tan drástica del esfuerzo de pesca (>80\% de los días de pesca al final de los cinco años de simulación) que, en la práctica, puede considerarse su aplicación no realista, ya que representaría una actividad muy baja de las flotas durante el año.

Palabras clave: pesquerías demersales; gestión de pesquerías; esfuerzo de pesca; Mediterráneo occidental.

Citation/Como citar este artículo: Martín P., Maynou F., Garriga-Panisello M., Ramírez J., Recasens L. 2019. Fishing effort alternatives for the management of demersal fisheries in the western Mediterranean. Sci. Mar. 83(4): 293-304. https:// doi.org/10.3989/scimar.04937.29B

Editor: E. Massutí.

Received: April 10, 2019. Accepted: October 24, 2019. Published: November 12, 2019.

Copyright: ( 2019 CSIC. This is an open-access article distributed under the terms of the Creative Commons Attribution 4.0 International (CC BY 4.0) License. 


\section{INTRODUCTION}

Demersal fisheries in the Mediterranean are typically multigear and multispecies. These fisheries are currently managed through national management plans, although the 2013 reform of the Common Fisheries Policy (EU 2013) foresees the application of multiannual fisheries management plans, coordinated at supranational level. The European Commission launched in 2018 a Proposal for a Regulation of the European Parliament and of the Council establishing a multiannual plan for fisheries exploiting demersal stocks in the western Mediterranean (EC 2018), including Spanish, French and Italian waters. For FAO geographical sub-area 6 (GSA 6), which is the area considered in this study (Fig. 1, northern Spain), this regulation applies to the main demersal species in the commercial fishery, viz. to blue and red shrimp Aristeus antennatus, deep-water rose shrimp Parapenaeus longirostris, European hake Merluccius merluccius, Norway lobster Nephrops norvegicus and red mullet Mullus barbatus.

Like other Mediterranean fisheries, GSA 6 demersal fisheries are managed by effort limitation and technical restrictions (e.g. seasonal and spatial closures; bottom trawl forbidden at $<50 \mathrm{~m}$ depth; characteristics of the fishing gear: $40-\mathrm{mm}$ square mesh trawl cod-end) and minimum conservation reference sizes established for EU Member States (Annex III of Council Regulation 1967/2006, the Mediterranean Regulation) and also set at national level (Spain) and by autonomous governments. These last two include additional minimum landing sizes, for species not considered in the EC Mediterranean Regulation (e.g. anglerfish, Lophius budegassa and Lophius piscatorius, four-spot megrim, Lepidorhombus bosci). To date, no total allowable catch (TAC) is implemented in demersal fisheries in the Mediterranean. Locally, additional fishing effort limitation is applied in certain areas (e.g. in some Aristeus antennatus fishing grounds and spatial closure in hake recruitment fishing grounds in the northern GSA 6).

The multigear and multispecies character of the demersal fisheries in the Mediterranean may result in the exploitation of a given species by different fishing gears. This is the case in our study area of European hake exploited by bottom trawl, gillnet and longline, and of striped red mullet (Mullus surmuletus) exploited by bottom trawl and trammel net. Moreover, bottom trawl strongly affects not only the main target species but also others that are highly vulnerable to bottom trawling (e.g. the greater forkbeard Phycis blennoides, by-catch of the red shrimp fishery).

According to standard stock assessments carried out by expert working groups of the Scientific, Technical and Economic Committee for Fisheries (STECF) and the General Fisheries Commission for the Mediterranean (GFCM), the current situation in the western Mediterranean is that some of the main demersal fishing targets are highly overexploited, with, for example, $\mathrm{F} / \mathrm{F}_{\mathrm{MSY}} \geq 5$ in the case of Merluccius merluccius and Mullus barbatus (GFCM 2017a,b, STECF 2018) and
$\mathrm{F} / \mathrm{F}_{\mathrm{MSY}} \geq 2$ in the case of Parapenaeus longirostris, Aristeus antennatus and Nephrops norvegicus (GFCM 2016, STECF 2017, 2018).

In the decision-making process, it is useful to work with different management alternatives to examine how successful they could be in the achievement of the management targets. To this aim, the Mediterranean Fisheries Simulation Tool (MEFISTO, Lleonart et al. 2003, Nielsen et al. 2018), a bioeconomic model specifically developed for Mediterranean fisheries, was chosen. MEFISTO simulates alternative management strategies (i.e. it is not an optimization model). It includes a population dynamics submodel, which simulates the dynamics of the stock, and an economic submodel. It is a useful simulation tool in the context of mixed fisheries because it shows the response of the stocks to different management measures. It produces $\mathrm{F}$ and $\mathrm{F} / \mathrm{F}_{\mathrm{MSY}}$ for each simulation scenario (i.e. for the various management measures that will be simulated), which can be compared against the stock assessment results. MEFISTO has been applied preferentially in Mediterranean demersal fisheries, but also in pelagic fisheries, e.g. a bottom trawl fishery in the Balearic Islands (Merino et al. 2015); small-scale and bottom trawl fisheries in the northern Aegean Sea (Maravelias et al. 2014); a small-scale lagoon fishery in the western Mediterranean (Maynou et al. 2014); and a small pelagic fishery in the northern Adriatic Sea (Silvestri and Maynou 2009). MEFISTO is an age-based model that is multispecies and multigear. It can be an advisory tool, as it allows different management options to be tested, including those typically used in Mediterranean fisheries management. For characteristics of the model and a detailed documentation of MEFISTO, see Lleonart et al. (2003), Merino et al. (2015) and Nielsen et al. (2018).

The aim of this study was to test different management alternatives for the demersal fisheries in the western Mediterranean on the basis of fishing effort, with the novelty of examining management alternatives at temporal scales smaller than one year. The approach is multispecies and multigear. The scenarios considered include seasonal closures of different durations and a decrease in the fishing effort of the fleets targeting demersal resources at different levels (bottom trawl and small-scale fleets). The study area is FAO geographical sub-area 6, northern Spain (GSA 6, Fig. 1).

\section{MATERIALS AND METHODS}

\section{Input data}

The fishing activity is carried out near the port base, five days a week, and the catch is marketed fresh daily upon arrival of the vessels at the port. The catch of the demersal fisheries (bottom trawl, entangling nets and longline) in the study area has steadily decreased in the last few years, from a peak of around 29000 tonnes in 2006 to 24000 tonnes in 2015, that is, a decrease of 17\% according to Data Collection Framework (DCF). At the same time, the fishing fleet has decreased by 30\%, from 698 trawlers, 886 entangling nets (mainly 


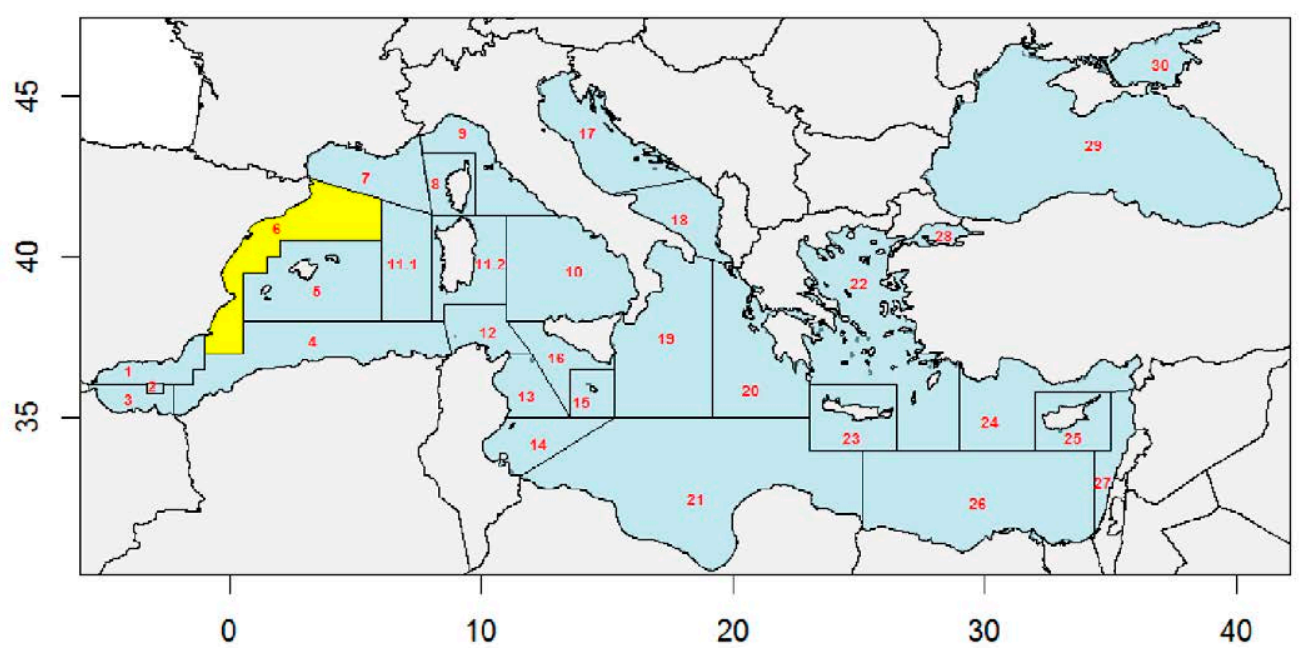

Fig. 1. - Study area: GSA 6, northern Spain. Geographical subareas as established by the General Fisheries Commission for the Mediterranean (GFCM).

trammel net and also gillnet) and 82 longliners in 2006, to 457, 649 and 71, respectively, in 2016 (EC Fleet Register).

A total of 10 species were selected, including the main target species of the demersal fisheries in GSA 6 , as well as the most vulnerable species. The selection of the species was made taking into account $(i)$ the five stocks that define the demersal fisheries, according to the EC proposal establishing a multiannual plan for the fisheries exploiting demersal stocks in the western Mediterranean Sea, GSA 6; (ii) species with a minimum landing size; (iii) the importance of the species in terms of landings and income; and (iv) the species' vulnerability to bottom trawl, based on the results of a productivity and susceptibility analysis (Patrick et al. 2009) performed for this purpose (DRuMFISH 2018), which showed the most vulnerable species to be greater forkbeard, anglerfish, black-bellied angler, four-spot megrim and European hake.

The species are the following: European hake Merluccius merluccius, Norway lobster Nephrops norvegicus, red mullet Mullus barbatus, striped red mullet Mullus surmuletus, deep-water rose shrimp Parapenaeus longirostris, anglerfish Lophius piscatorius, black-bellied angler Lophius budegassa, blue and red shrimp Aristeus antennatus, greater forkbeard Phycis blennoides and four-spot megrim Lepidorhombus boscii. Most of these species are fished exclusively by bottom trawl, but in some cases the species catch comes from different gears, each one targeting a given size (or age) range (e.g. Merluccius merluccius, Mullus barbatus, Mullus surmuletus, Lophius piscatorius and Lophius budegassa). Bottom trawl catches are in all cases much higher and sizes (or ages) smaller than those of the small-scale gears with which the resource is shared. The selected species represent around $26 \%$ of the demersal fisheries catch in GSA 6 and around 57\% of income from sale at auction in 2015 (DCF). Their relative importance in the demersal fisheries in GSA 6 is shown in Table 1. The data used in this study come from the EC Data Collection Framework (DCF 2016) and stock assessment results. The data taken from the DCF include landings, discards, length-frequency distributions and fishing fleet characteristics. MEFISTO start-up requires the establishment of an initial stock situation. The model carries out forward projections starting from the current situation of the stocks and fleets under different conditions, i.e. the management options that will be analysed. The input data required regarding the stock status correspond to the mean value of the last three years assessed in the reports indicated in Table 1. Stock assessment results were taken from the assessments performed by STECF and GFCM Stock Assessment Working Groups. In some cases, i.e. when the information in the reports did not allow the calculation of this three-year mean value or when the

Table 1. - Selected species: landings and income in GSA 6 in 2015 (DCF) and length-weight relationship and growth parameters (VBGC) used to run MEFISTO, taken from referenced assessments. Lepidorhombus boscii (LDB) had not been assessed previously (ANK, Lophius budegassa; ARA, Aristeus antennatus; DPS, Parapenaeus longirostris; GFB, Phycis blennoides; HKE, Merluccius merluccius; LDB, Lepidorhombus boscii; MON, Lophius piscatorius; MUR, Mullus surmuletus; MUT, Mullus barbatus; NEP, Nephrops novegicus).

\begin{tabular}{lcccccccccc}
\hline Stockname & $(\mathrm{t})$ & Landings $(\%)$ & $(\mathrm{k} €)$ & Income $(\%)$ & $\mathrm{a}$ & $\mathrm{b}$ & Linf & $\mathrm{K}$ & $\mathrm{t}_{0}$ & $\mathrm{Reference}$ \\
\hline ANK & 858.0 & 3.5 & 303.0 & 0.3 & 0.0232 & 2.85 & 102.0 & 0.15 & -0.05 & STECF $(2015 \mathrm{~b})$ \\
ARA & 689.7 & 2.8 & 22052.3 & 20.9 & 0.0020 & 2.51 & 77.0 & 0.38 & -0.07 & STECF $(2015 \mathrm{a})$ \\
DPS & 177.4 & 0.7 & 2963.5 & 2.8 & 0.0031 & 2.49 & 45.0 & 0.39 & 0.00 & STECF $(2013 \mathrm{a})$ \\
GFB & 399.3 & 1.6 & 1143.8 & 1.1 & 0.0034 & 3.25 & 49.3 & 0.31 & -0.09 & STECF $(2013 \mathrm{~b})(\mathrm{GSA} 09)$ \\
HKE & 1778.2 & 7.3 & 12404.7 & 11.8 & 0.0068 & 3.04 & 110.0 & 0.18 & 0.00 & STECF $(2015 \mathrm{a})$ \\
LDB & 84.3 & 0.3 & 29.8 & 0.0 & 0.0643 & 2.27 & 45.6 & 0.15 & -0.59 & Landa et al. 2016 \\
MON & 179.3 & 0.7 & 3999.5 & 3.8 & 0.0182 & 2.93 & 140.0 & 0.11 & -0.70 & STECF (2017) \\
MUR & 226.0 & 0.9 & 1309.0 & 1.2 & 0.0084 & 3.12 & 40.1 & 0.16 & -1.88 & GFCM (2015) (GSA05) \\
MUT & 1569.3 & 6.5 & 6285.4 & 6.0 & 0.0062 & 3.16 & 34.5 & 0.34 & -0.14 & GFCM (2015) \\
NEP & 361.6 & 1.5 & 8957.4 & 8.5 & 0.0010 & 3.08 & 74.1 & 0.17 & 0.00 & STECF (2017) \\
\hline
\end{tabular}


Table 2. - Recruitment timing, by species and month, expressed in percentage. Species codes as in Table 1.

\begin{tabular}{ccccccccccc}
\hline Month & ANK & ARA & DPS & GFB & HKE & LDB & MON & MUR & MUT & NEP \\
\hline 1 & 0.24 & 0.00 & 0.22 & 0.00 & 0.01 & 0.00 & 0.23 & 0.00 & 0.00 & 0.00 \\
2 & 0.23 & 0.00 & 0.28 & 0.00 & 0.01 & 0.00 & 0.27 & 0.00 & 0.00 & 0.00 \\
3 & 0.15 & 0.00 & 0.28 & 0.00 & 0.01 & 0.00 & 0.27 & 0.00 & 0.00 & 0.00 \\
4 & 0.00 & 0.15 & 0.22 & 0.00 & 0.01 & 0.00 & 0.23 & 0.00 & 0.00 & 0.00 \\
5 & 0.00 & 0.23 & 0.00 & 0.22 & 0.01 & 0.23 & 0.00 & 0.00 & 0.00 & 0.23 \\
6 & 0.00 & 0.24 & 0.00 & 0.28 & 0.01 & 0.27 & 0.00 & 0.00 & 0.00 & 0.27 \\
7 & 0.00 & 0.23 & 0.00 & 0.28 & 0.22 & 0.27 & 0.00 & 0.00 & 0.00 & 0.27 \\
8 & 0.00 & 0.15 & 0.00 & 0.22 & 0.24 & 0.23 & 0.00 & 0.00 & 0.00 & 0.23 \\
9 & 0.00 & 0.00 & 0.00 & 0.00 & 0.24 & 0.00 & 0.00 & 0.30 & 0.30 \\
10 & 0.00 & 0.00 & 0.00 & 0.00 & 0.22 & 0.00 & 0.00 & 0.40 & 0.40 \\
11 & 0.15 & 0.00 & 0.00 & 0.00 & 0.01 & 0.00 & 0.00 & 0.30 & 0.00 \\
12 & 0.23 & 0.00 & 0.00 & 0.00 & 0.01 & 0.00 & 0.00 & 0.00 & 0.00 \\
\hline
\end{tabular}

Table 3. $-\mathrm{F}_{\mathrm{bar}}$ used in the simulations. Species codes as in Table 1.

\begin{tabular}{llll}
\hline Species & \multicolumn{2}{c}{ Age range } & References \\
\hline ANK & 1 & 4 & STECF $(2015 \mathrm{~b})$ \\
ARA & 1 & 3 & STECF $(2015 \mathrm{a})$ \\
DPS & 2 & 4 & STECF (2013a) \\
GFB & 1 & 3 & STECF $(2013 \mathrm{~b})$ \\
HKE & 1 & 3 & STECF (2015a) \\
LDB & 1 & 6 & This study \\
MON & 1 & 4 & STECF (2017) \\
MUR & 0 & 2 & GFCM (2015) \\
MUT & 1 & 2 & GFCM (2015) \\
NEP & 2 & 6 & STECF (2017) \\
\hline
\end{tabular}

species had not been previously assessed, these were generated with pseudo-cohort analysis (VIT; Lleonart and Salat 1997). Growth parameters (length-weight relationship and VBGC parameters) were the same as those used in the assessments (Table 1).

Within a gear, the catch of a species obtained by each fleet segment is different. The fleet segments as defined in the DCF are based on the length overall and are the following: VL0612 (6-12 m), VL1218 (12-18 $\mathrm{m}), \operatorname{VL} 1824$ (18-24 m) and VL2440 (24-40 m). The EC Fleet Register specifies the characteristics of each vessel (http://ec.europa.eu/fisheries/fleet/index.cfm). According to the overall vessel length, each vessel was assigned to its corresponding fleet segment. Fleet as used here corresponds to the combination of gear and fleet segment. A total of seven fleets were considered, three bottom otter trawl, two longline and two gillnet and trammel net. Fishing mortality by species and fleet was calculated from the total fishing mortality, $\mathrm{F}$, taken from the stock assessment and the corresponding landings by species and fleet. The DCF economic transversal data were used for this calculation (https://stecf.jrc. ec.europa.eu/web/stecf/reports/economic).

Recruitment timing by species and month, expressed in percentage, is shown in Table 2. Landings in GSA 6 display a marked seasonality, as elsewhere in the Mediterranean, and the landings peak corresponds to the recruitment timing. The definition of the recruitment timing for each stock was based on the landings trend during the year. $\mathrm{F}_{\mathrm{bar}}$ used in MEFISTO is the same as that used in the assessments (Table 3). Fishing mortality at age by fleet for each stock is presented in Table 4 , which shows the relative importance of each gear and fleet segment in the exploitation of each study species. Stock numbers of individuals at age (thousands) resulting from the latest assessments (mean values of the last three years) are given in Table 5.

\section{Management scenarios and reference points}

We considered nine simulation scenarios based on input control that took into account the following management measures: a decrease in the number of fishing days, which may correspond to cessation of activity of vessels or to lower activity of the fleet, and implementation of seasonal closures of one-, two- and threemonth duration in winter, spring, summer and autumn (Table 6). Gear selectivity remained unchanged.

Scenarios 1 and 2 simulate a $20 \%$ reduction in the number of fishing days by the end of five years of application of the management measure to all fleets (scenario 1) or to bottom trawl (scenario 2). Scenarios 3 and 4 apply annually to all fleets a $10 \%$ and $20 \%$ reduction, respectively, of the number of fishing days for five years. In scenario $530 \%$ reduction of fishing days is applied annually for five years, and in scenario 6 the $30 \%$ reduction will be achieved by the end of the five years of implementation of the measure. Scenarios 7 , 8 , and 9 apply seasonal closures of three, two and one months, respectively (Table 6). When the fleets return to their activity after the temporal cessation, the number of fishing days is the same as before the closure. Scenario 1 corresponds to the Spanish management plan for the conservation of fishing resources in the Mediterranean for the period 2013-2017 (BOE 2012), aimed at reducing at least $20 \%$ of the total fishing effort, measured as number of vessels, horsepower or tonnage, by the end of the implementation of the plan. Our scenario 3 is in line with the recently approved multiannual plan for demersal fisheries in the western Mediterranean, which calls for a reduction of $40 \%$ effort during the 2019-2024 period. The reduction in the number of fishing days resulting from the five-year implementation of the scenarios is given in Table 6. TAC or quota were not considered as possible management tools because Mediterranean fisheries are traditionally managed with input measures (effort limitations, technological restrictions). Table 7 shows the $\mathrm{F}_{\mathrm{MSY}}$ values that are used as a reference for calculating the ratio $\mathrm{F} /$ $\mathrm{F}_{\mathrm{MSY}}$ resulting from the MEFISTO scenarios. $\mathrm{F}_{0.1}$ resulting from yield per recruit analysis was taken as a proxy for $\mathrm{F}_{\mathrm{MSY}}$.

The duration of the simulations was 15 years and the model initialization, i.e. the time required to rebuild the spawning stock biomass (SSB), was set to 15 years. The management scenarios were applied during five consecutive years after the model initialization. Re- 
Table 4. - Fishing mortality. F at age by fleet for each stock. Fleet code indicates gear and vessel length (OTB, bottom otter trawl; LLS,

\begin{tabular}{|c|c|c|c|c|c|c|c|c|}
\hline stock & age & OTBVL1218 & OTBVL1824 & OTBVL2440 & LLSVL0612 & LLSVL1218 & DFNVL0612 & DFNVL1218 \\
\hline ANK & 0 & 0.004 & 0.004 & 0.005 & 0.000 & 0.000 & 0.000 & 0.000 \\
\hline ANK & 1 & 0.068 & 0.073 & 0.086 & 0.002 & 0.000 & 0.006 & 0.000 \\
\hline ANK & 2 & 0.431 & 0.465 & 0.543 & 0.010 & 0.000 & 0.036 & 0.000 \\
\hline ANK & 3 & 0.384 & 0.414 & 0.484 & 0.009 & 0.000 & 0.032 & 0.000 \\
\hline ANK & 4 & 0.187 & 0.201 & 0.235 & 0.004 & 0.000 & 0.016 & 0.000 \\
\hline ANK & 5 & 0.318 & 0.344 & 0.401 & 0.007 & 0.000 & 0.027 & 0.000 \\
\hline ANK & 6 & 1.314 & 1.418 & 1.655 & 0.030 & 0.000 & 0.110 & 0.000 \\
\hline ANK & 7 & 0.618 & 0.667 & 0.779 & 0.014 & 0.000 & 0.052 & 0.000 \\
\hline ANK & 8 & 0.618 & 0.667 & 0.779 & 0.014 & 0.000 & 0.052 & 0.000 \\
\hline ARA & 0 & 0.000 & 0.001 & 0.001 & 0.000 & 0.000 & 0.000 & 0.000 \\
\hline ARA & 1 & 0.012 & 0.283 & 0.476 & 0.000 & 0.000 & 0.000 & 0.000 \\
\hline ARA & 2 & 0.014 & 0.315 & 0.530 & 0.000 & 0.000 & 0.000 & 0.000 \\
\hline ARA & 3 & 0.011 & 0.259 & 0.437 & 0.000 & 0.000 & 0.000 & 0.000 \\
\hline ARA & 4 & 0.011 & 0.247 & 0.415 & 0.000 & 0.000 & 0.000 & 0.000 \\
\hline DPS & 0 & 0.000 & 0.000 & 0.000 & 0.000 & 0.000 & 0.000 & 0.000 \\
\hline DPS & 1 & 0.007 & 0.045 & 0.041 & 0.000 & 0.000 & 0.000 & 0.000 \\
\hline DPS & 2 & 0.080 & 0.512 & 0.465 & 0.000 & 0.000 & 0.000 & 0.000 \\
\hline DPS & 3 & 0.124 & 0.791 & 0.718 & 0.000 & 0.000 & 0.000 & 0.000 \\
\hline DPS & 4 & 0.151 & 0.965 & 0.876 & 0.000 & 0.000 & 0.000 & 0.000 \\
\hline DPS & 5 & 0.119 & 0.760 & 0.690 & 0.000 & 0.000 & 0.000 & 0.000 \\
\hline DPS & 6 & 0.119 & 0.760 & 0.690 & 0.000 & 0.000 & 0.000 & 0.000 \\
\hline GFB & 0 & 0.002 & 0.021 & 0.024 & 0.000 & 0.000 & 0.000 & 0.000 \\
\hline GFB & 1 & 0.030 & 0.277 & 0.306 & 0.005 & 0.001 & 0.000 & 0.000 \\
\hline GFB & 2 & 0.028 & 0.254 & 0.281 & 0.004 & 0.001 & 0.000 & 0.000 \\
\hline GFB & 3 & 0.005 & 0.044 & 0.049 & 0.001 & 0.000 & 0.000 & 0.000 \\
\hline HKE & 0 & 0.010 & 0.061 & 0.064 & 0.004 & 0.004 & 0.002 & 0.003 \\
\hline HKE & 1 & 0.103 & 0.655 & 0.693 & 0.043 & 0.047 & 0.018 & 0.032 \\
\hline HKE & 2 & 0.123 & 0.778 & 0.824 & 0.051 & 0.056 & 0.022 & 0.039 \\
\hline HKE & 3 & 0.111 & 0.708 & 0.749 & 0.046 & 0.051 & 0.020 & 0.035 \\
\hline HKE & 4 & 0.066 & 0.422 & 0.446 & 0.028 & 0.030 & 0.012 & 0.021 \\
\hline HKE & 5 & 0.066 & 0.422 & 0.446 & 0.028 & 0.030 & 0.012 & 0.021 \\
\hline LDB & 0 & 0.001 & 0.001 & 0.000 & 0.000 & 0.000 & 0.000 & 0.000 \\
\hline LDB & 1 & 0.092 & 0.091 & 0.013 & 0.000 & 0.000 & 0.002 & 0.000 \\
\hline LDB & 2 & 0.205 & 0.203 & 0.029 & 0.000 & 0.000 & 0.005 & 0.000 \\
\hline LDB & 3 & 0.250 & 0.248 & 0.036 & 0.000 & 0.000 & 0.006 & 0.000 \\
\hline LDB & 4 & 0.231 & 0.229 & 0.033 & 0.000 & 0.000 & 0.005 & 0.000 \\
\hline LDB & 5 & 0.171 & 0.170 & 0.025 & 0.000 & 0.000 & 0.004 & 0.000 \\
\hline LDB & 6 & 0.046 & 0.045 & 0.007 & 0.000 & 0.000 & 0.001 & 0.000 \\
\hline MON & 0 & 0.006 & 0.025 & 0.017 & 0.000 & 0.000 & 0.001 & 0.001 \\
\hline MON & 1 & 0.052 & 0.218 & 0.146 & 0.002 & 0.003 & 0.006 & 0.007 \\
\hline MON & 2 & 0.043 & 0.181 & 0.121 & 0.002 & 0.002 & 0.005 & 0.006 \\
\hline MON & 3 & 0.026 & 0.107 & 0.072 & 0.001 & 0.001 & 0.003 & 0.004 \\
\hline MON & 4 & 0.017 & 0.071 & 0.048 & 0.001 & 0.001 & 0.002 & 0.002 \\
\hline MON & 5 & 0.014 & 0.059 & 0.039 & 0.000 & 0.001 & 0.002 & 0.002 \\
\hline MON & 6 & 0.016 & 0.065 & 0.043 & 0.001 & 0.001 & 0.002 & 0.002 \\
\hline MON & 7 & 0.028 & 0.116 & 0.077 & 0.001 & 0.001 & 0.003 & 0.004 \\
\hline MON & 8 & 0.036 & 0.151 & 0.101 & 0.001 & 0.002 & 0.004 & 0.005 \\
\hline MON & 9 & 0.016 & 0.068 & 0.045 & 0.001 & 0.001 & 0.002 & 0.002 \\
\hline MON & 10 & 0.235 & 0.984 & 0.658 & 0.008 & 0.011 & 0.027 & 0.033 \\
\hline MUR & 0 & 0.008 & 0.019 & 0.007 & 0.000 & 0.000 & 0.017 & 0.019 \\
\hline MUR & 1 & 0.053 & 0.119 & 0.044 & 0.001 & 0.001 & 0.107 & 0.121 \\
\hline MUR & 2 & 0.080 & 0.178 & 0.066 & 0.001 & 0.001 & 0.161 & 0.181 \\
\hline MUR & 3 & 0.099 & 0.220 & 0.082 & 0.002 & 0.001 & 0.200 & 0.224 \\
\hline MUR & 4 & 0.069 & 0.154 & 0.058 & 0.001 & 0.001 & 0.140 & 0.157 \\
\hline MUR & 5 & 0.060 & 0.135 & 0.050 & 0.001 & 0.001 & 0.122 & 0.137 \\
\hline MUR & 6 & 0.012 & 0.026 & 0.010 & 0.000 & 0.000 & 0.024 & 0.027 \\
\hline MUT & 0 & 0.004 & 0.007 & 0.006 & 0.000 & 0.000 & 0.000 & 0.000 \\
\hline MUT & 1 & 0.209 & 0.440 & 0.331 & 0.000 & 0.000 & 0.022 & 0.022 \\
\hline MUT & 2 & 0.449 & 0.943 & 0.709 & 0.000 & 0.000 & 0.047 & 0.046 \\
\hline MUT & 3 & 0.280 & 0.588 & 0.442 & 0.000 & 0.000 & 0.029 & 0.029 \\
\hline MUT & 4 & 0.020 & 0.042 & 0.032 & 0.000 & 0.000 & 0.002 & 0.002 \\
\hline NEP & 0 & 0.002 & 0.010 & 0.006 & 0.000 & 0.000 & 0.000 & 0.000 \\
\hline NEP & 1 & 0.053 & 0.325 & 0.211 & 0.000 & 0.000 & 0.000 & 0.000 \\
\hline NEP & 2 & 0.139 & 0.855 & 0.556 & 0.000 & 0.000 & 0.000 & 0.000 \\
\hline NEP & 3 & 0.125 & 0.766 & 0.498 & 0.000 & 0.000 & 0.000 & 0.000 \\
\hline NEP & 4 & 0.118 & 0.723 & 0.470 & 0.000 & 0.000 & 0.000 & 0.000 \\
\hline NEP & 5 & 0.116 & 0.713 & 0.463 & 0.000 & 0.000 & 0.000 & 0.000 \\
\hline NEP & 6 & 0.116 & 0.713 & 0.463 & 0.000 & 0.000 & 0.000 & 0.000 \\
\hline
\end{tabular}

cruitment was assumed constant during the simulation period. In the Mediterranean fisheries it has not been possible to establish convincing SSB per recruit relationships for the main stocks. The economic module of MEFISTO was disabled because we were interested in the biological response of the stocks to the management scenarios.

The MEFISTO software, which includes full documentation on the model and a user guide, can be downloaded at http://mefisto2017.wordpress.com/ 
Table 5. - Stock numbers at age (thousands) resulting from the latest assessments (mean values of the last three years). Species codes as in Table 1

\begin{tabular}{lrrrrrrrrrrr}
\hline ages & 0 & 1 & 2 & 3 & 4 & 5 & 6 & 7 & 8 & 9 & 10 \\
\hline ANK & 12073 & 4430 & 2490 & 304 & 56 & 29 & 12 & 1 & 2 & - & - \\
ARA & 203197 & 56406 & 4690 & 866 & 269 & - & - & - & - & - & - \\
DPS & 110227 & 27784 & 11712 & 2867 & 411 & 45 & - & - & - & - & - \\
GFB & 25045 & 7981 & 2597 & 1003 & - & - & - & - & - & - & - \\
HKE & 102767 & 26775 & 2792 & 226 & 34 & 6 & - & - & - & - & - \\
LDB & 5154 & 3518 & 1973 & 862 & 345 & 142 & 68 & - & - & - & - \\
MON & 905 & 308 & 125 & 65 & 39 & 25 & 17 & 11 & 7 & 4 & 1 \\
MUR & 25885 & 8954 & 3376 & 1250 & 426179 & 85 & - & - & - & - \\
MUT & 116359 & 42682 & 10042 & 666 & 39 & - & - & - & - & - & - \\
NEP & 53856 & 33138 & 16596 & 4459 & 1445558 & 249 & - & - & - & - \\
\hline
\end{tabular}

\section{RESULTS}

We simulated the dynamics of the stocks under nine management strategies; scenario 0 corresponds to the status quo, the initial situation of the stocks. The results in terms of $\mathrm{F}_{\mathrm{bar}}$ and $\mathrm{F}_{\mathrm{bar}} / \mathrm{F}_{\mathrm{MSY}}$ are shown in Tables 8 and 9, respectively. As is to be expected, because all scenarios represent a substantial fishing effort reduction, $\mathrm{F}_{\mathrm{bar}}$ at the end of the simulation is smaller than at the beginning (status quo). The change in $\mathrm{F}_{\mathrm{bar}}$ is similar in scenarios 1 and 2 (20\% reduction in fishing days for the five-year period of implementation applied to all fleets or only to bottom otter trawl fleets), indicating that most of the fishing mortality applied corresponds to bottom otter trawl. The exception is striped red mullet, one of the main targets of small-scale fishing, namely, entangling nets. A similar decrease in $\mathrm{F}$ results from a $20 \%$ reduction in the number of fishing days (scenarios 1 and 2) and from the implementation of temporal closures of three or two months (scenarios 7 and 8). The temporal cessation of activity for one month (scenario 9) leads to a very slight decrease in fishing mortality.

Since the biological characteristics and the initial stock status are different, the management target of $\mathrm{F}_{\mathrm{bar}} \leq \mathrm{F}_{\mathrm{MSY}}$ is reached under different scenarios, depending on the stock. The initial status was of overexploitation in most of the stocks at the start of the simulation (Table 9, scenario 0). For some of the main bottom trawl targets, the status is of very high overexploitation. This is the case of, for example, of Norway lobster, European hake, black-bellied angler and deep-water rose shrimp. These stocks would achieve or would be close to $\mathrm{F}_{\mathrm{bar}} \leq \mathrm{F}_{\mathrm{MSY}}$ only under a very drastic effort reduction of more than $80 \%$ of fishing days (scenario 5).

MEFISTO simulation results are shown for scenarios 1,5 and 7 (Fig. 2). These scenarios correspond to the management measures in the 2013-2017 Spanish management plan for the conservation of fishing

Table 6. - Simulation scenarios. The total fishing days reduction corresponding to each scenario by the end of the five-year simulation period is given in the right column.

\begin{tabular}{|c|c|c|}
\hline Scenario & Description & days reduction \\
\hline 0 & Status quo & \\
\hline 1 & $20 \%$ reduction of fishing days by the end of 5 years of simulation applied to all fleets. & $20 \%$ \\
\hline 2 & $20 \%$ reduction of fishing days by the end of 5 years of simulation applied to OTB fleets. & $20 \%$ \\
\hline 3 & $10 \%$ annual reduction of fishing days during 5 years of simulation applied to all fleets. & $41 \%$ \\
\hline 4 & $20 \%$ annual reduction of fishing days during 5 years of simulation applied to all fleets. & $67 \%$ \\
\hline 5 & $30 \%$ annual reduction of fishing days during 5 years of simulation, applied to all fleets & $83 \%$ \\
\hline 6 & $30 \%$ reduction of fishing days during 5 years of simulation, applied to all fleets. & $30 \%$ \\
\hline 7 & 3-month closure applied to OTB. & \\
\hline 8 & 2-month closure applied to OTB & \\
\hline 9 & 1-month closure applied to OTB & \\
\hline
\end{tabular}

Table 7. $-\mathrm{F}_{\mathrm{MSY}}$ estimated in the assessments. These $\mathrm{F}_{\mathrm{MSY}}$ values are used as a reference for calculating the F/FMSY ratio resulting from the MEFISTO scenarios. Species codes as in Table 1.

\begin{tabular}{llccc}
\hline Species Code & \multicolumn{1}{c}{ Scientific name } & $\mathrm{F}_{\text {MSY }}\left(\mathrm{F}_{0.1 \text { YperR }}\right)$ & Assessment Method & References \\
\hline ANK & Lophius budegasa & 0.140 & XSA & STECF (2015b) \\
ARA & Aristeus antennatus & 0.360 & XSA & STECF (2015a) \\
DPS & Parapenaeus longirostris & 0.269 & XSA & STECF (2013a) \\
GFB & Phycis blennoides & 0.780 & VIT & This study \\
HKE & Merluccius merluccius & 0.260 & XSA & STECF (2015a) \\
LDB & Lepidorhombus boscii & 0.903 & VIT & This study \\
MON & Lophius piscatorius & 0.467 & VIT & This study \\
MUR & Mullus surmuletus & 0.663 & VIT & GFCM (2015) \\
MUT & Mullus barbatus & 0.449 & XSA & STECF (2017) \\
NEP & Nephrops norvegicus & 0.175 & XSA &
\end{tabular}

Table 8. $-\mathrm{F}_{\text {bar }}$ by stock under the nine scenarios considered after five consecutive years of implementation of the measures of fishing effort reduction. Definition of the scenarios in Table 6 and species codes as in Table 1.

\begin{tabular}{lccccccccccc}
\hline Scenarios & 0 & 1 & 2 & 3 & 4 & 5 & 6 & 7 & 9 \\
\hline ANK & 0.921 & 0.737 & 0.742 & 0.544 & 0.302 & 0.155 & 0.645 & 0.698 & 0.772 & 0.847 \\
ARA & 0.779 & 0.623 & 0.623 & 0.460 & 0.255 & 0.131 & 0.545 & 0.584 & 0.649 & 0.714 \\
DPS & 1.561 & 1.249 & 1.249 & 0.922 & 0.511 & 0.262 & 1.093 & 1.171 & 1.301 & 1.431 \\
GFB & 0.429 & 0.343 & 0.344 & 0.253 & 0.140 & 0.072 & 0.300 & 0.323 & 0.358 & 0.393 \\
HKE & 1.734 & 1.387 & 1.418 & 1.024 & 0.568 & 0.291 & 1.214 & 1.339 & 1.470 & 1.602 \\
LDB & 0.494 & 0.395 & 0.396 & 0.291 & 0.162 & 0.083 & 0.346 & 0.371 & 0.412 & 0.453 \\
MON & 0.287 & 0.230 & 0.232 & 0.169 & 0.094 & 0.048 & 0.201 & 0.218 & 0.241 & 0.264 \\
MUR & 0.395 & 0.316 & 0.356 & 0.233 & 0.129 & 0.066 & 0.276 & 0.347 & 0.363 & 0.379 \\
MUT & 1.609 & 1.287 & 1.301 & 0.950 & 0.527 & 0.270 & 1.126 & 1.224 & 1.352 & 1.480 \\
NEP & 1.366 & 1.093 & 1.093 & 0.807 & 0.448 & 0.230 & 0.957 & 1.025 & 1.139 & 1.253 \\
\hline
\end{tabular}


Table 9. $-\mathrm{F}_{\mathrm{bar}} / \mathrm{F}_{\mathrm{MSY}}$ under the nine management scenarios considered after five consecutive years of implementation of the measures of fishing effort reduction. $\mathrm{F}_{\mathrm{MSY}}$ value is given in Table 7. Definition of the scenarios in Table 6 and species codes as in Table 1.

\begin{tabular}{|c|c|c|c|c|c|c|c|c|c|c|}
\hline Scenarios & 0 & 1 & 2 & 3 & 4 & 5 & 6 & 7 & 8 & 9 \\
\hline ANK & 6.58 & 5.26 & 5.30 & 3.88 & 2.16 & 1.11 & 4.60 & 4.98 & 5.52 & 6.05 \\
\hline ARA & 2.16 & 1.73 & 1.73 & 1.28 & 0.71 & 0.36 & 1.51 & 1.62 & 1.80 & 1.98 \\
\hline DPS & 5.80 & 4.64 & 4.64 & 3.43 & 1.90 & 0.98 & 4.06 & 4.35 & 4.84 & 5.32 \\
\hline GFB & 0.55 & 0.44 & 0.44 & 0.32 & 0.18 & 0.09 & 0.38 & 0.41 & 0.46 & 0.50 \\
\hline HKE & 6.67 & 5.34 & 5.45 & 3.94 & 2.19 & 1.12 & 4.67 & 5.15 & 5.66 & 6.16 \\
\hline LDB & 0.55 & 0.44 & 0.44 & 0.32 & 0.18 & 0.09 & 0.38 & 0.41 & 0.46 & 0.50 \\
\hline MON & 0.61 & 0.49 & 0.50 & 0.36 & 0.20 & 0.10 & 0.43 & 0.47 & 0.52 & 0.57 \\
\hline MUR & 0.60 & 0.48 & 0.54 & 0.35 & 0.20 & 0.10 & 0.42 & 0.52 & 0.55 & 0.57 \\
\hline MUT & 3.58 & 2.87 & 2.90 & 2.12 & 1.17 & 0.60 & 2.51 & 2.73 & 3.01 & 3.30 \\
\hline NEP & 7.81 & 6.25 & 6.25 & 4.61 & 2.56 & 1.31 & 5.47 & 5.86 & 6.51 & 7.16 \\
\hline
\end{tabular}

Scenario 1
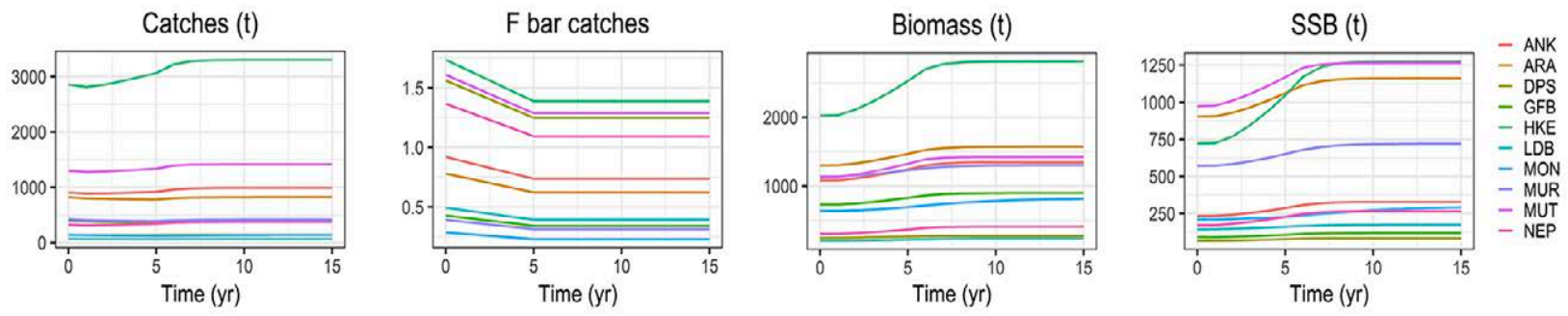

\section{Scenario 5}
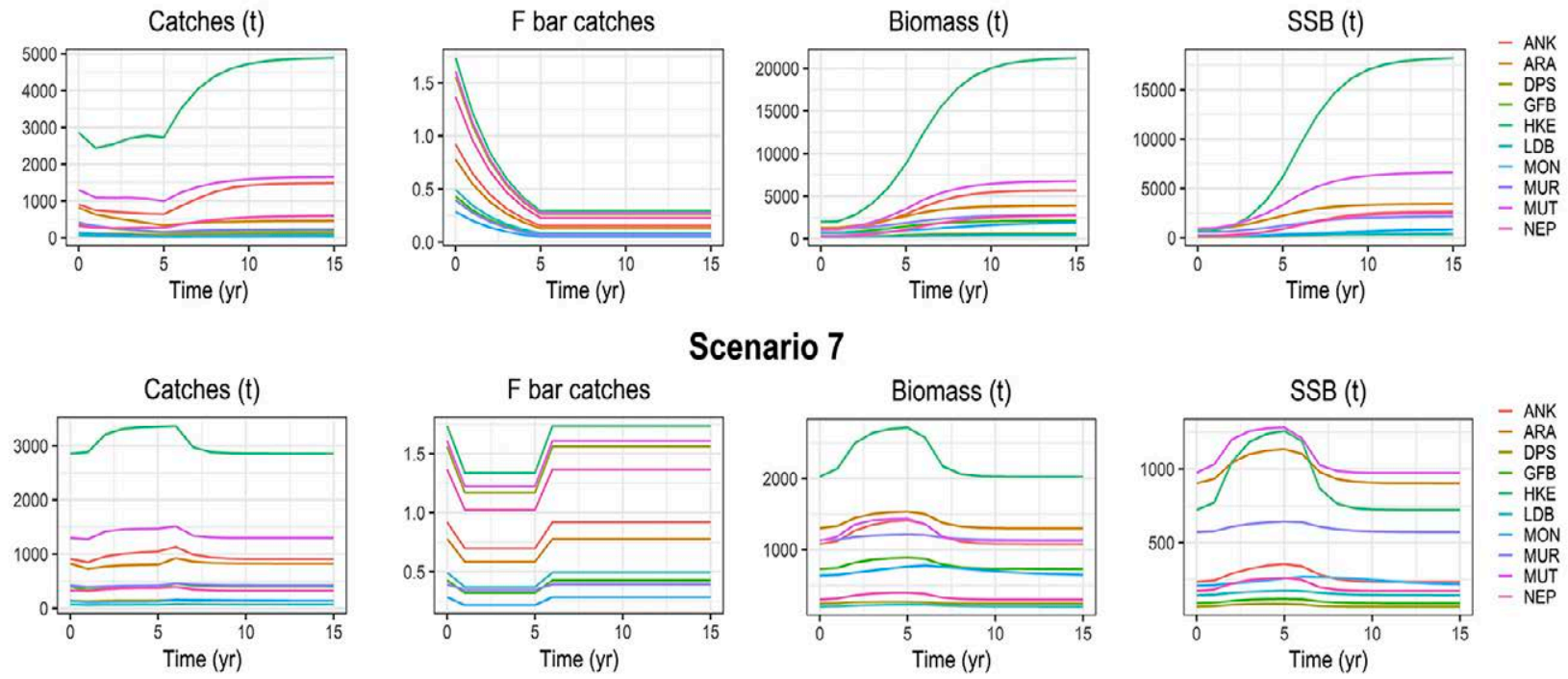

Fig. 2. - Catches, $\mathrm{F}_{\mathrm{bar}}$, biomass and spawning stock biomass (SSB) trend over 15 years of simulation under the implementation of scenarios 1 ( $20 \%$ reduction of fishing days by the end of five years of simulation applied to all fleets), 5 (30\% annual reduction of fishing days during five years of simulation applied to all fleets) and 7 (three-month closure applied to otter bottom trawl, winter).

resources (scenario 1), the scenario under which the status of all the stocks would be $\mathrm{F}_{\mathrm{bar}} \leq \mathrm{F}_{\mathrm{MSY}}$ (scenario 5 ), and the results from a seasonal closure of three months (scenario 7, winter). Exploitation is based on the younger ages, 0 to 2 . Since most species are heavily exploited, the reaction to a decrease in fishing effort is rapid, despite the different biological characteristics of each species. Scenario 1 shows the gradual decrease imposed on the fishing days, to reach a $20 \%$ reduction in relation to the starting value at the end of the five-year period of implementation of the measure. This reduction runs simultaneously to increasing catches, biomass and SSB, which remain higher after the five-year implementation than at the beginning of the simulation. Scenario 5 shows-along with the marked decrease in $\mathrm{F}$ resulting from the very drastic decrease in the fishing activity-the increase in catches, biomass and SSB. In scenario 7, the effect of the implementation of the seasonal closure is evident during the five years when this measure is implemented, but afterwards, since the fishing effort is the same as at the beginning, catches, biomass and SSB gradually decrease to the initial values, and the effect of the closure is lost in the years following the cessation of the measure. During the implementation of the management measures, F decreases and SSB increases at a different rate depending on the scenario. The F and SSB trend during the five years when the effort reduction is applied is shown in Figure 3 for scenarios 1 and 5 . 

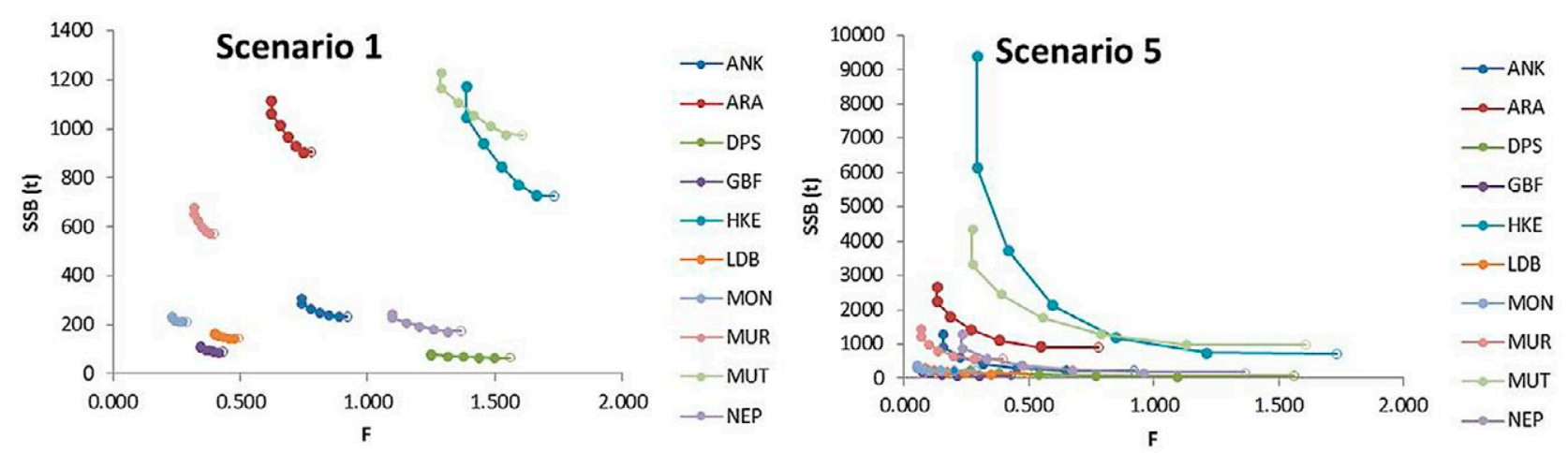

Fig 3. - Fishing mortality $\left(\mathrm{F}_{\text {bar }}\right)$ and SSB trend during five consecutive years of implementation of scenarios 1 and 5 and in year 6 after the implementation period of the fishing effort restrictions. Empty circle corresponds to status quo. Trends go from right to left (decreasing F) and upwards (increasing SSB).
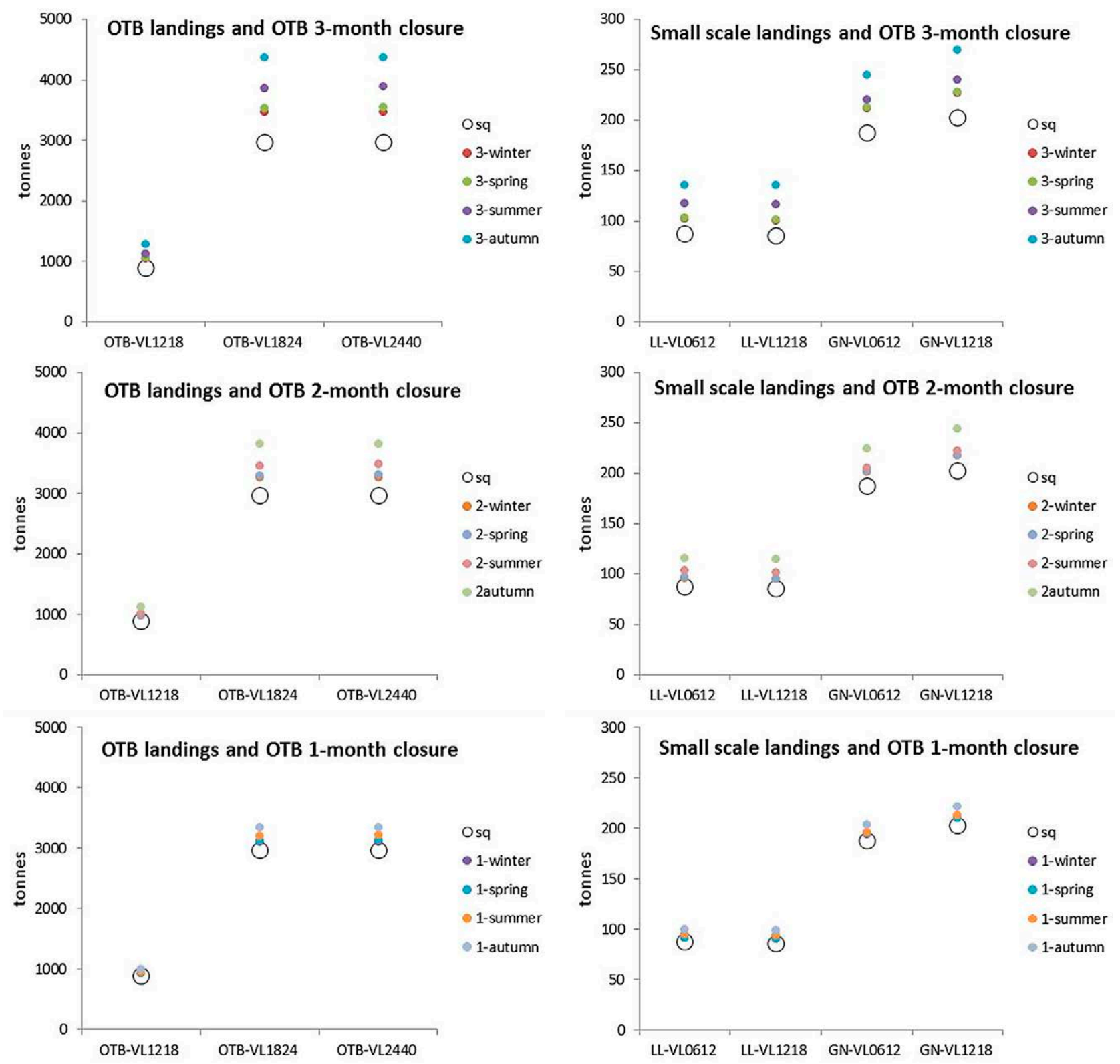

Fig. 4. - Catches by gear and fleet segment (left column, otter bottom trawl; right column, small-scale fishing) after five consecutive years of implementation of otter bottom trawl seasonal closures of three, two and one months. Note that small-scale fishing gears benefit from these closures. 

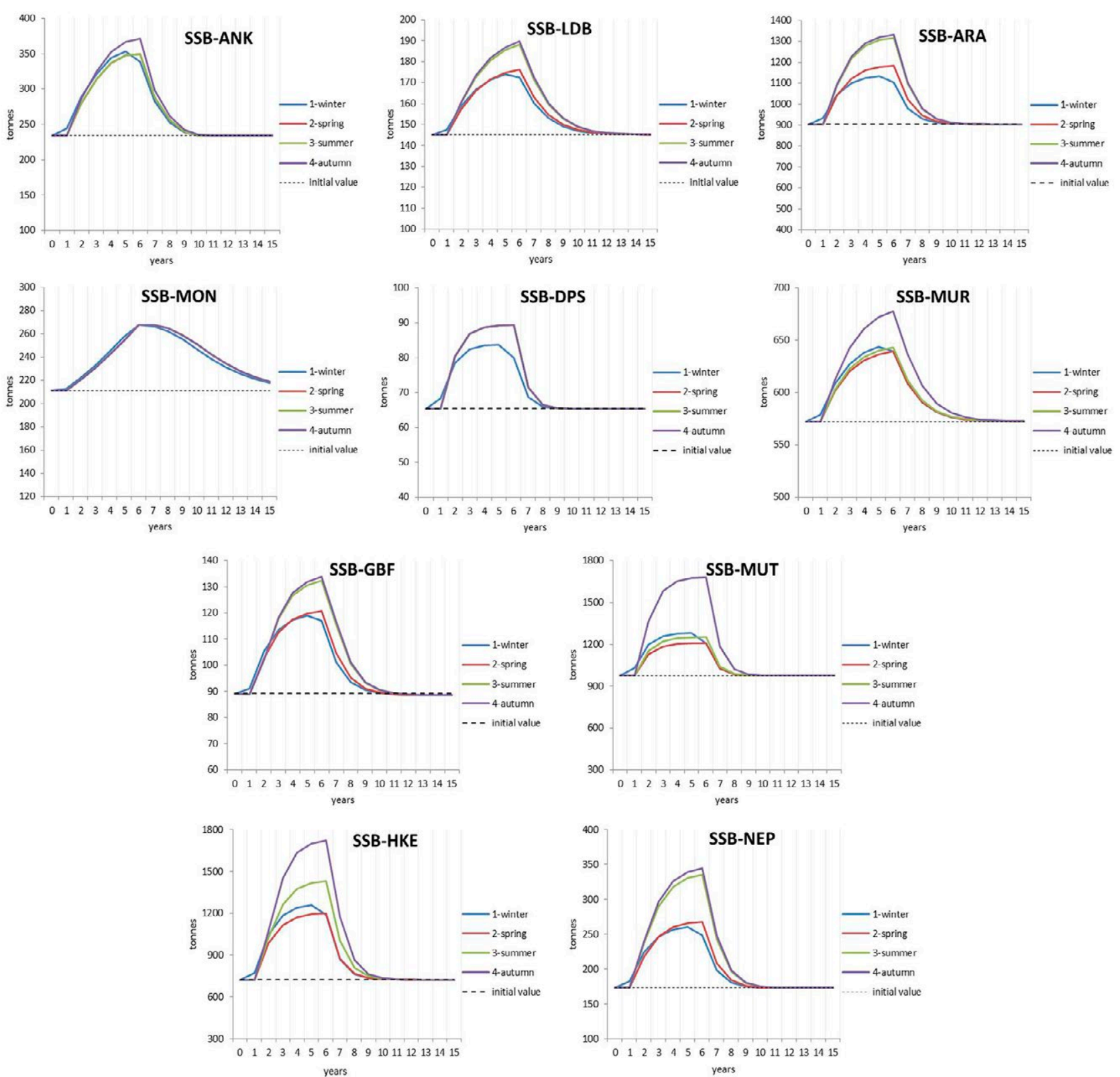

Fig. 5. - SSB trend over 15 years of simulation under the implementation of a three-month closure for the otter bottom trawl fleets in winter, spring, summer and autumn.

Temporal cessation of fishing activity is a very widely implemented management measure in the Mediterranean. In GSA 6 the duration is between one and two months, depending on the zone, and it is implemented at different times of the year. We examined the effects of a seasonal closure of bottom otter trawl for one, two and three months on bottom otter trawl and small-scale overall catches of the selected stocks and the influence of the time of the year when the closure was implemented (Fig. 4). It is worth noting that the longer the closure, the higher the landings are and, interestingly, the small-scale fleets clearly benefit from bottom otter trawl closures. Within bottom otter trawl, the higher increase corresponds to VL1824 and VL2440, while in the case of longline and gillnet and trammel net all segments respond similarly. As for the most appropriate timing for the seasonal closure, results of SSB trend, which depend on the recruitment timing of each stock, suggest that it is in autumn that the highest SSB is achieved for most of the selected species (Fig. 5). The species with recruitment to the fishery that takes place in autumn, or partially in autumn, are those that would take more advantage of the closure in this season, such as as hake, Norway lobster, red mullet, striped red mullet and blue and red shrimp. Autumn would also be an appropriate period for the closure for the vulnerable species identified, greater forkbeard and four-spot megrim. SSB returns to the initial values since the fishing activity was the same before and after the implementation of the closure. The effect of the closure was apparent in the following two, three or even more years, depending on the species, after the cessation of the five-year implementation of the measure. 


\section{DISCUSSION}

This study is interesting in that it reveals the response of the stocks to different management measures while addressing features characteristic of Mediterranean demersal fisheries, such as the interaction between fishing gears and competition for common resources. This is why a management measure applied to a fishing fleet may affect other fleets not concerned by the measure. Indeed, the results highlight benefits for small-scale fishing expressed as increased catches when bottom trawl effort decreased.

Generally, all species will benefit from a seasonal reduction of fishing effort. Depending on their biology, closures affect the stocks differently. Particular attention was given to seasonal closures, since this is a management measure widely applied in the Mediterranean, with differences in duration and in the fleets concerned. Temporal cessation of the fishing activity for bottom trawl has been implemented for many years in GSA 6. These closures have changed over time in duration, time of year and zone. At present, 2019, the duration of these closures is one or two months, depending on the harbour or district within GSA 6, and they are implemented at different times of year, mainly in late spring and summer but also in winter (BOE 2018a, b, c, d). Therefore, seasonal closures are not applied in autumn, the time of the year most favourable for SSB recovery for most of the stocks considered in this study, as the results suggest. As for the duration, the closure effect on decreasing $\mathrm{F}$ would be limited when the duration is one month. It is worth noting that a similar decrease in $\mathrm{F}$ is achieved with a $20 \%$ reduction of fishing effort and with two- to threemonth closures (Table 8, scenarios 1-2 and 7-8). This observation is a useful tool for managers because it highlights that different alternatives aimed at reducing fishing mortality may provide similar results regarding the conservation of the stocks. With these reductions in fishing effort, however, several of the studied species would be far from achieving the target maximum sustained yield (MSY). In general, complying with international agreements imposing fishing at MSY will require strong fishing mortality reductions over a short time-frame (Maynou 2014).

The most recent assessments of demersal stocks in the western Mediterranean, by GSAs and combinations of GSAs, refer to hake, red mullet, Norway lobster, deep-water rose shrimp, blue and red shrimp and giant red shrimp (STECF 2018). They coincide with the previous stocks assessments used here in that the Mediterranean assessed stocks are in overexploitation, with the exception of red mullet in the southern and central Thyrrenian (GSA 10) and deep-water rose shrimp in the Ligurian and northern Thyrrenian seas (GSA 9). The European Parliament recently stressed the lack of consistency between the plans for western Mediterranean demersal fisheries adopted by France, Italy and Spain and stated that these plans have proven ineffective for meeting the objectives set in the Common Fisheries Policy (European Parliament 2019). Our results are in line with this observation.
Simulation results of scenario 1, which corresponds to the fishing effort reduction provided for in the 20132017 Spanish management plan for the conservation of fishing resources, indicate that the $20 \%$ reduction of fishing effort over the five years leads to an increase in catches, biomass and SSB and a decrease in F during the five years, and that afterwards, catches, biomass and SSB stabilize at a higher level than the initial one and $F$ remains at a lower level than the initial one. Nevertheless, the implementation of scenario 1 would not lead to the target $\mathrm{F}_{\mathrm{bar}} / \mathrm{F}_{\mathrm{MSY}}=1$, although this plan would represent a major reduction of the fleet, additional to that implemented in the previous management plan. It is impossible to achieve MSY simultaneously across all species. This target would be jointly achieved by the stocks considered only with such a drastic reduction of fishing effort ( $83 \%$ of fishing days by the end of the simulation; scenario 5) that, in practice, its application seems unrealistic because it would mean a very low activity throughout the year. This reduction in fishing effort to achieve MSY is greater than those proposed for other fisheries. Merino et al. (2015) proposed 71\% reductions for the bottom trawl fishery in the Balearic Islands (GSA 5), an area where the most important demersal resources are in a better state than in GSA 6 , but still overexploited. Such drastic reductions in fishing effort might be unnecessary to achieve $\mathrm{F}_{\mathrm{MSY}}$ if Mediterranean fisheries are oriented towards selective fishing practices (Maynou 2014).

Although most of the fishing mortality is exerted by bottom otter trawl, fishing mortality by small-scale fisheries, basically trammel net and longline, is not to be considered negligible. For instance, a 53\% reduction in the fishing effort of the small-scale fisheries in the Balearic Islands was proposed to keep the stocks exploited in shallower waters than the bottom trawl fisheries below their MSY (Quetglas et al. 2016). The small-scale fisheries change the target species during the year and usually operate during key life-history periods, such as when spawners concentrate. This is, for example, the case the hake fishery in the Gulf of Lions (GSA 7), where the species was exploited in a more diversified way than in other areas, the whole population becoming accessible to fishing. By the late 1980s, hake was exploited by trawl (196 units), gillnet (20 units) and longline (13 units). In 1988 the total annual hake landings in that area amounted to 5882 t (Aldebert and Recasens 1993). Three decades later, in 2016, the presence in the catch of $>40 \mathrm{~cm}$ TL individuals had drastically decreased and the annual landings amounted to $1029.3 \mathrm{t}$. The fleet consisted of 75 trawlers, 122 gillnetters and entangling netters and 6 longliners (GFCM 2017a).

The greater forkbeard and four-spot megrim, vulnerable species included in the study according to their stock status (Tables 8 and 9), would not be overexploited. Their corresponding fishing mortality was much lower than that of the main fishing targets (e.g. hake, red mullet, Norway lobster and deep-water rose shrimp). They are by-catch species of bottom trawl, the catch of the small-scale fisheries being negligible. Four-spot megrim landings are low, although the spe- 
cies, unlike the greater forkbeard, is well accepted by consumers. Nevertheless, results show that any measure aimed at reducing bottom trawl fishing effort based on the status of the main target stocks would be beneficial for both four-spot megrim and greater forkbeard. Cook and Heath (2018) propose that the assessments of target species give a broad indication of the likely exploitation and biomass trends in by-catch species, although there will be differences depending on the species and fisheries concerned.

Two aspects that are important for sound management of fishing effort, the spatial distribution of fishing effort and its re-allocation, have not been dealt with in this study. This information is currently available for bottom trawl. However, in order to implement measures related to the spatial distribution of effort, we also need to obtain precise knowledge of the target species' distribution throughout their life cycle (e.g. areas where spawners or recruits concentrate) and to identify the most intensively exploited fishing grounds for the implementation of spatial closures or rotation of areas, for example. Furthermore, it is not generally possible to assign the specific fishing effort to each species, but information is available, so in the near future this is expected to be feasible.

Some issues of the management of fishing effort are not dealt with in MEFISTO. The model does not consider the spatial dimension of fisheries, nor can account for effort distribution within fleet segments endogenously. To date, very few bioeconomic models are fully spatially oriented (see review in Nielsen et al. 2018), but Russo et al. (2014) provides an application of the SMART model to demersal fisheries in the Sicily Strait, which, although highly data-demanding, is a first step towards an operative model that allows spatial management of fishing effort to be included as a tool for the management of fisheries.

TAC or quota were not considered as possible management tools because demersal fisheries in the Mediterranean have been, and are, managed with input measures (effort limitations, technological restrictions). At present, the implementation of the western Mediterranean multiannual plan for the demersal fisheries proposed by the European Commission (2018) has been adopted. The European Parliament rejected management measures based on TACs because they are not appropriate for the Mediterranean, given the difficulty in applying this measure in multi-specific fisheries where stocks are shared with non-EU countries. It would be preferable to apply technical measures to improve the state of the stock by reducing the fishing mortality of the target species where appropriate (European Parliament 2019).

In conclusion, this study provides relevant input for the management of demersal resources. For the effect of temporal closures to persist beyond the five years of implementation, their duration should be longer than one month. Autumn would be the most appropriate season, taking into account the species' behaviour in the area. The limitation of the bottom trawl activity aimed at reducing fishing mortality would also benefit the small-scale fishing.

\section{ACKNOWLEDGEMENTS}

This study was partially funded by the project DRuMFISH (EASME/EMFF/2014/1.3.2.4/ SI2.721116). We thank the EC Directorate-General for Maritime Affairs and Fisheries (Directorate MARE) for providing the Data Collection Framework data for GSA 6.

\section{REFERENCES}

Aldebert Y., Recasens L. 1993. Analysis of gear interactions in a hake fishery: The case of the Gulf of Lions (NW Mediterranean). Sci. Mar. 57: 207-217.

BOE. 2012. Orden AAA/2808/2012, de 21 de diciembre, por la que se establece un Plan de Gestión Integral para la conservación de los recursos pesqueros en el Mediterráneo afectados por las pesquerías realizadas con redes de cerco, redes de arrastre y artes fijos y menores, para el período 2013-2017. https://www.boe.es/boe/dias/2012/12/29/pdfs/BOEA-2012-15740.pdf

BOE. 2018a. Orden APM/85/2018, de 31 de enero, por la que se establecen vedas temporales para la pesca de la modalidad de arrastre en determinadas zonas del litoral de Cataluña. https://www.boe.es/boe/dias/2018/02/01/pdfs/BOEA-2018-1412.pdf

BOE. 2018b. Orden APM/429/2018, de 27 de abril, por la que se establece una veda temporal para la pesca en la modalidad de arrastre de fondo en el litoral de la provincia de Tarragona. https://www.boe.es/boe/dias/2018/04/28/pdfs/BOEA-2018-5838.pdf

BOE. 2018c. Orden APM/430/2018, de 27 de abril, por la que se establece una veda temporal para la pesca en la modalidad de arrastre en el litoral de la Región de Murcia. https://www.boe.es/boe/dias/2018/04/28/pdfs/BOEA-2018-5839.pdf

BOE. 2018d. Orden APM/431/2018, de 27 de abril, por la que se establecen vedas temporales para la pesca en la modalidad de arrastre de fondo en el litoral de la Comunitat Valenciana. https://www.boe.es/boe/dias/2018/04/28/pdfs/BOEA-2018-5840.pdf

Cook R.M., Heath M.R. 2018. Population trends of bycatch species reflect improving status of target species. Fish Fish. 19: 455-470. https://doi.org/10.1111/faf.12265

Council Regulation 1967/2006. 2006. Council Regulation (EC) No $1967 / 2006$ of 21 December 2006 concerning management measures for the sustainable exploitation of fishery resources in the Mediterranean Sea, amending Regulation (EEC) No $2847 / 93$ and repealing Regulation (EC) No 1626/94.

DRuMFISH. 2018. Study on the Approaches to Management for Data-Poor Stocks in Mixed Fisheries. Contract Number EASME/EMFF/2014/1.3.2.4/ SI2.721116

European Commission (EC). 2018. Proposal for a Regulation of the European Parliament and of the Council establishing a multiannual plan for fisheries exploiting demersal stocks in the western Mediterranean Sea. COM/2018/0115 final. https://ec.europa.eu/info/law/better-regulation/initiatives/ com-2018-115_en

European Union (EU). 2013. Regulation (EU) No 1380/2013 of the European Parliament and of the Council of 11 December 2013 on the Common Fisheries Policy, amending Council Regulations (EC) No 1954/2003 and (EC) No 1224/2009 and repealing Council Regulations (EC) No 2371/2002 and (EC) No 639/2004 and Council Decision 2004/585/EC.

European Parliament. 2019. Committee on Fisheries. A8-0005/2019. Report on the proposal for a regulation of the European Parliament and of the Council establishing a multi-annual plan for the fisheries exploiting demersal stocks in the western Mediterranean Sea (COM (2018)0115 - C8-0104/2018 - 2018/0050(COD)).

General Fisheries Commission for the Mediterranean (GFCM). 2015. Stock Assessment Forms.

https://gfcmsitestorage.blob.core.windows.net/documents/ SAC/SAFs/DemersalSpecies/2015/MUR_GSA_05_2015_ ESP.pdf

General Fisheries Commission for the Mediterranean (GFCM). 2016. Scientific Advisory Committee on Fisheries (SAC). 
Working Group on Stock Assessment of Demersal Species (WGSAD). GFCM and FAO headquarters, Rome, Italy, 7-12 November 2016. Final Report.

http://www.fao.org/gfcm/reports/technical-meetings/detail/ en/c/471253/

General Fisheries Commission for the Mediterranean (GFCM). 2017a. Stock Assessment Forms

https://gfcmsitestorage.blob.core.windows.net/documents/ SAC/SAFs/DemersalSpecies/2016/HKE_GSA_07_2016_ FRA_ESP.pdf

General Fisheries Commission for the Mediterranean (GFCM). 2017b. Scientific Advisory Committee on Fisheries (SAC). Working Group on Stock Assessment of Demersal Species (WGSAD). FAO headquarters, Rome, Italy, 13-18 November 2017. Final Report.

http://www.fao.org/gfcm/reports/technical-meetings/detail/ en/c/1105308/

Landa J., Fontenla J. 2016. Age and growth of four spot megrim (Lepidorhombus boscii) in northern Iberian waters corroborated by cohort tracking. Est. Coast. Shelf Sci. 179: 181-188. https://doi.org/10.1016/j.ecss.2016.01.010

Lleonart J, Salat J. 1997. VIT: Software for fishery analysis. User's manual. FAO Computerized Information Series (Fisheries). $\mathbf{N}^{\circ}$ 11, FAO, Rome. 105 pp.

Lleonart J., Maynou F., Recasens L., et al. 2003. A bio-economic model for Mediterranean fisheries, the hak off Catalonia (western Mediterranean) as a case study. Sci. Mar. 67 (Suppl. 1): 337-351. https://doi.org/10.3989/scimar.2003.67s1337

Maravelias C.D., Pantazi M., Maynou F. 2014. Fisheries management scenarios: trade-offs between economic and biological objectives. Fish. Manage. Ecol. 21: 186-195. https://doi.org/10.1111/fme.12060

Maynou F. 2014. Coviability analysis of Western Mediterranean fisheries under MSY scenarios for 2020. ICES J. Mar. Sci. 71: 1563-1571.

https://doi.org/10.1093/icesjms/fsu061

Maynou F, Martínez-Baños P., Demestre M., et al. 2014. Bioeconomic analysis of the Mar Menor (Murcia, SE Spain) smallscale lagoon fishery. J. Appl. Ichthyol. 30: 978-985. https://doi.org/10.1111/jai.12460

Merino G., Quetglas A., Maynou F., et al. 2015. Improving the performance of a Mediterranean demersal fishery toward economic objectives beyond MSY. Fish. Res. 161: 131-144. https://doi.org/10.1016/j.fishres.2014.06.010

Nielsen J.R., Thunberg E., Holland D.S., et al. 2018. Integrated ecological-economic fisheries models-Evaluation, review and challenges for implementation. Fish Fish. 19: 1-29. https://doi.org/10.1111/faf.12232

Patrick W.S., Spencer P., Ormseth O., et al. 2009. Use of Productivity and Susceptibility Indices to Determine Stock Vulnerability, with Example Applications to Six U.S. Fisheries. U.S. Department of Commerce. NOAA Tech. Memorandum NMFS-F/ SPO-101, October 2009. 90 pp.

Quetglas A., Merino G., Ordines F., et al. 2016. Assessment and management of western Mediterranean small-scale fisheries. Ocean Coast. Manage. 133: 95-104. https://doi.org/10.1016/j.ocecoaman.2016.09.013

Russo T., Parisi A., Garofalo G., et al. 2014. SMART: A Spatially Explicit Bio-Economic Model for Assessing and Managing Demersal Fisheries, with an Application to Italian Trawlers in the Strait of Sicily. PLoS ONE 9: e86222. https://doi.org/10.1371/journal.pone.0086222

Silvestri S., Maynou F. 2009. Application of a bioeconomic model for supporting the management process of the small pelagic fishery in the Veneto Region, northern Adriatic Sea, Italy. Sci. Mar. 73: 563-572.

https://doi.org/10.3989/scimar.2009.73n3563

Scientific, Technical and Economic Committee for Fisheries (STECF). 2013a. Assessment of Mediterranean Sea stocks part I (STECF 13-22). Publ. Office European Union, Luxembourg, EUR $26329 \mathrm{EN}$ https://doi.org/10.2788/36268

Scientific, Technical and Economic Committee for Fisheries (STECF). 2013b. Assessment of Mediterranean Sea stocks part II (STECF 13-05). Publ. Office European. Union, Luxembourg, EUR 25309 EN.

https://doi.org/10.2788/89997

Scientific, Technical and Economic Committee for Fisheries (STECF). 2015a. Mediterranean assessments part 1 (STECF-15-18). Publ. Office European. Union, Luxembourg, EUR 27638 EN. https://doi.org/10.2788/406771

Scientific, Technical and Economic Committee for Fisheries (STECF). 2015b. Mediterranean Assessments part 2 (STECF-15-06). Publ. Office European. Union, Luxembourg, EUR 27221 EN. https://doi.org/10.2788/20044

Scientific, Technical and Economic Committee for Fisheries (STECF). 2017. Mediterranean assessments 2016- part 2 (STECF-17-06). Publ. Office European. Union, Luxembourg; EUR 28359 EN. https://doi.org/10.2760/015005

Scientific, Technical and Economic Committee for Fisheries (STECF). 2018. Mediterranean Stock Assessments - Part 1 (STECF-18-12). Publ. Office European. Union, Luxembourg. EUR 28359 EN. https://doi.org/10.2760/838965 